\title{
Antiviral activity of ciprofloxacin on BK virus in an in vitro culture - pilot study
}

\author{
Justyna Pasternak', Barbara Rajtar', Agnieszka Stec ${ }^{1}$, Małgorzata Polz-Dacewicz' \\ ${ }^{1}$ Department of Virology, Medical University of Lublin
}

Pasternak J, Rajtar B, Stec A, Polz-Dacewicz M. Antiviral activity of ciprofloxacin on BK virus in an in vitro culture - pilot study. J Pre-Clin Clin Res. 2017; 11(2): 116-119. doi: 10.26444/jpccr/78587

\begin{abstract}
Introduction. Reactivation of BKV infection caused by decrease of immunity associated with organ transplantation can lead to nephropathy and organ loss. Antiviral drugs such as ganciclovir or foscarnet did not display any activity against BK virus. A source of hope can be found in chemotherapeutics usually used in bacterial infections that inhibit the replication of viral genetic material in cells. One of the aforementioned chemotherapeutics is ciprofloxacin. The aim of the study is to evaluate the antiviral activity of ciprofloxacin against BK virus in vitro culture.

Materials and method. Initially, the effects of ciprofloxacin on Vero cell viability were assessed with MTT. After determining the 3 largest non-cytotoxic concentrations of antibiotics, their effect on viral replication in cells was determined. 24-h cells culture in DMEM medium supplemented with $10 \%$ serum after $2 \mathrm{~h}$ incubation with a $6.3 \times 10^{5} \mathrm{copies} / \mathrm{ml}$ infection virus were used to evaluate the effects of different concentrations of ciprofloxacin on the number of BKV copies. Quantification of BKV replication in the culture was performed by real-time PCR.

Results. By means of the MTT test, the 3 largest non-cytotoxic ciprofloxacin concentrations were determined as follows: $31.25 ; 62.5 ; 125 \mu \mathrm{g} / \mathrm{ml}$. Cells treated with ciprofloxacin at a concentration of $125 \mu \mathrm{g} / \mathrm{ml}$ display the greatest decrease in BKV replication that equaly $1.8-3 \mathrm{log} / 5.8-9.2 \mathrm{Ct}$, compared to the control of the virus without drugs. A decline in the number of copies of the virus was observed during the lower concentration of the antibiotic $(62.5,31.25 \mu \mathrm{g} / \mathrm{ml}) \mathrm{by} 1.3-2 \mathrm{log} / 4-6.4$ $\mathrm{Ct}$ and $0-0.8 \mathrm{log} / 0-2,4 \mathrm{Ct}$, respectively.

Conclusions. Ciprofloxacin exhibits antiviral activity against the BK virus by inhibiting its replication in the in vitro culture in Vero cell line.
\end{abstract}

\section{Key words}

ciprofloxacin, antiviral activity, BK virus

\section{INTRODUCTION}

The human body is colonized by a number of viruses and bacteria which do not pose a threat to healthy people. They become a problem only when the human immunity is weakened, which results in their reactivation. BK polyomavirus is one of such viruses. Routes of transmission of the virus are not fully recognised, although the likely among these routes are: inhalation, oral-faecal, blood, a transplanted organ or the placenta. Its prevalence affect in the population occurs when more than $80 \%$ of specific antibodies are detected. The infection usually occurs during early childhood; in healthy individuals, however, the infection is asymptomatic or is manifested by not very characteristic symptoms. The virus then goes into a latent state and locates itself in the urogenital system, spleen, tonsils or peripheral blood mononuclear cells (PBMC), and may reactivate due to the weakened immunity [1].

The main site of the virus is the urinary tract, which is the reason why the signs of active infection are usually observed there. The most common renal complications described in literature are tubulo-interstitial nephritis, urethrostenosis and nephropathy [2]. In $10 \%$ of recipients of bone marrow, the BKV infection is manifested by haemorrhagic cystitis. In addition to the aforementioned direct effects, the

Adress for correspondence: Justyna Pasternak, Department of Virology, Medical University of Lublin, Witolda Chodźki 1, 20-093 Lublin, Poland

E-mail: justyna.pasternak3@gmail.com

Received: 7 August 2017; accepted: 13 October 2017 predispositions to colorectal cancer are observed [3,4]. Along with the progress in the field of organ transplantation, including kidneys, there is a growing range of powerful immunosuppressive therapies. On the one hand, they result in longer transplant retention, at the same time, however, they lead to the activation of opportunistic pathogens in the recipient. One of them is the $\mathrm{BK}$ virus that carries a risk of developing nephropathy and a risk of graft loss [5, 6]. Hence, there is the need to seek an effective antiviral therapy that will prevent the development of viraemia/ viruria, thus avoiding subsequent complications. One of the recommended medicines is ciprofloxacin, a synthetic antibiotic that belongs to the group of fluoroquinolones. In addition to the antiviral activity operating on the basis of the inhibition of helicase activated by the large tumour antigen ( $\mathrm{T} \mathrm{Ag}$ ) of the BK virus, it also has antibacterial activity based on the inhibition of bacterial DNA synthesis resulting from blocking topoisomerase type II and IV $[3,7]$.

\section{OBJECTIVE}

The aim of the study is to evaluate the antiviral activity of ciprofloxacin against the BK virus in an in vitro culture by establishing the highest effective dose of chemotherapeutic that is non-toxic to the cells, and capable of inhibiting BKV replication. 


\section{MATERIALS AND METHOD}

Cell and virus. Vero cells were obtained from the European Collection of Cell Cultures (ECACC No. 84113001) and maintained in DMEM medium containing $10 \%$ foetal bovine serum, $100 \mu \mathrm{g} / \mathrm{ml}$ streptomycin and $100 \mathrm{U} / \mathrm{ml}$ penicillin. Cells were cultivated in a humidified incubator with $5 \% \mathrm{CO}_{2}$ at $37^{\circ} \mathrm{C}$. For antiviral activity of ciprofloxacin, BK virus (ATCC No. VR-837) from the American Type Culture Collection was used. The virus was propagated in the Vero cell culture. Virus stock was stored at $-70^{\circ} \mathrm{C}$ until used.

Cell viability assay. The cell viability was measured using the MTT test. Cells were seeded at a density of $1.5 \times 10^{5}$ cells $/ \mathrm{ml}$ onto 96 -well plates. After $24 \mathrm{~h}$ of incubation, the cells were treated with $2-1000 \mu \mathrm{g} / \mathrm{ml}$ ciprofloxacin for $48 \mathrm{~h}$. At every stage of the experiment, the control of the cells containing cultured cells without ciprofloxacin was included. After incubation at $37^{\circ} \mathrm{C}$, in the presence of $5 \% \mathrm{CO}_{2}$, the quantitative determination of cell viability by MTT was performed.

Ciprofloxacin. Ciprofloxacin was obtained from Polpharma (Poland). For the evaluation of antiviral properties of ciprofloxacin, the 24-hour cultures of cells in DMEM supplemented by $10 \%$ serum and established in 24 -well culture plates were used. Afterwards, the cells were infected with the virus diluted in the medium supplemented with $2 \%$ serum at doses of $6.3 \times 10^{5} ; 6.3 \times 10^{4} ; 6.3 \times 10^{3} ; 6.3 \times 10^{2}$ copies $/ \mathrm{ml}$ and subjected to $2 \mathrm{~h}$ of incubation. After removal of the virus, the cells were exposed to the antibiotic at 3 nontoxic concentrations: $31.25 ; 62.5 ; 125 \mu \mathrm{g} / \mathrm{ml}$, established in the previous step. The prepared and described plate was stored for 7 days at $37^{\circ} \mathrm{C}$ in the presence of $5 \% \mathrm{CO}_{2}$.

Isolation of viral DNA. Conducted using DNA Blood MiniKit (QIAGEN), in accordance with the standard procedure provided by the manufacturer, changing the elution volume to $50 \mu$ l.

Real-time PCR. The real-time polymerase chain reaction (real-time PCR) method was used to detect BKV in the specimens. With the aim of detecting the genetic material of BKV, the primers described by Arthur et al. [8]: PEP1 (5' AGTCTTTAGGGTCTTCTACC 3') and PEP-2 (5' GGTGCCAACCTATGGAACAG $3^{\prime}$ ) were used. The oligonucleotides bind to a highly conservative early region coding the T Ag. Primers amplify a 176-bp fragment of the BKV genetic material. The final PCR reaction mixture contained SybrAdvantage qPCR Premix x2 (Takara), $0,3 \mu$ l of each primer (final concentration $0,2 \mu \mathrm{M}$ ) and $3 \mu$ l of extracted sample. The amplification conditions were as follows: $95^{\circ} \mathrm{C}$ for $20 \mathrm{sec}$ then $45 \mathrm{cyces}$ of $95^{\circ} \mathrm{C}$ for $5 \mathrm{sec}$ and $60^{\circ} \mathrm{C}$ for $40 \mathrm{sec}$.

The results of the assay are expressed as $\Delta \mathrm{Ct}$ - difference between $\mathrm{Ct}$ for virus isolates from infected cells treated with different concentrations of ciprofloxacin, and $\mathrm{Ct}$ for the virus control (isolates without ciprofloxacin added). Quantitative analysis was based on a standard curve using 10 -fold dilutions of BK virus in the range of $6.3 \times 10^{1}-6.3 \times 10^{6} \mathrm{copies} / \mathrm{ml}$. The virus genome copy number was shown in log.

Statistical analysis. All assays were performed in triplicates and the data analyzed using one way Analysis of Variance
(ANOVA) with Tukey post-hoc test $(\mathrm{p}<0.05)$ using Statistica 9.1 .

\section{RESULTS}

Based on the results obtained from the MTT assay, 3 ciprofloxacin concentrations non-toxic to the cell were selected: $125 ; 62.5 ; 31.25 \mu \mathrm{g} / \mathrm{ml}$. The efficacy of the drug was then evaluated for different copies of BKV using real-time PCR.

Evaluation of the effects of different concentrations of ciprofloxacin on BKV replication. Based on the qPCR analysis, it was confirmed that ciprofloxacin inhibits the replication of BK virus in vitro in Vero cells culture. In each of the 3 repetitions for the infectious BKV dose of $6.3 \times 10^{5} \mathrm{copies} / \mathrm{ml}$, a decrease in the amount of the virus under the influence of ciprofloxacin was observed, depending on the concentration of the antibiotic. Cells treated with ciprofloxacin at $125 \mu \mathrm{g} / \mathrm{ml}$ showed the greatest decrease in BKV replication level of $1.8-3 \log / 5.8-9.2 \mathrm{Ct}(\mathrm{p}=0.0003)$, compared to the virus control without the addition of ciprofloxacin. In lower concentrations of the antibiotic (62.5, $31.25 \mu \mathrm{g} / \mathrm{ml}$ ), a reduction in the viraemia level was also observed. For ciprofloxacin at concentrations of $62.5 \mu \mathrm{g} / \mathrm{ml}$ and $31.25 \mu \mathrm{g} / \mathrm{ml}$ a decrease of the viraemia level was observed by $1.3-2 \log / 4-6.4 \mathrm{Ct}$ and $0-0.8 \log / 0-2.4 \mathrm{Ct}$, respectively. For the concentration of $62.5 \mu \mathrm{g} / \mathrm{ml}$ this decrease was statistically significant $(p=0.001)$; for the concentration of $31.25 \mu \mathrm{g} / \mathrm{ml}$ it was not statistically significant $(\mathrm{p}=0.66)$.

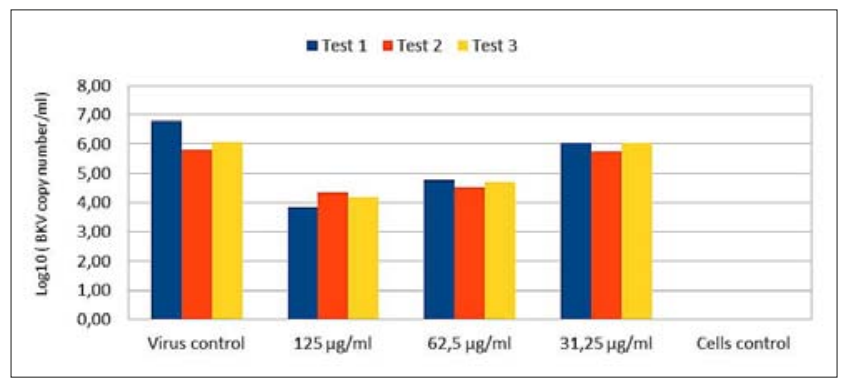

Figure 1. Effect of different concentrations of ciprofloxacin on BKV replication

Virus control - infected cells without ciprofloxacin: 125; 62,$5 ; 31,25 \mu \mathrm{g} / \mathrm{ml}$ - concentration of ciprofloxacin; Cells control - not infected cells without ciprofloxacin.

Evaluation of the effects of ciprofloxacin on BK replication based on the infectious dose of the virus. The effect of ciprofloxacin on BKV replication in cells infected with lower viral load was also studied. For this purpose, three 10 -fold dilutions of $6.3 \times 10^{4} ; 6.3 \times 10^{3} ; 6.3 \times 10^{2}$ copies $/ \mathrm{ml}$ were used to infect the culture. Ciprofloxacin in concentrations of 125; $62.5 ; 31.25 \mu \mathrm{g} / \mathrm{ml}$ was used. At the BKV level of $6.3 \times 10^{4}$ copies $/ \mathrm{ml}$, like in the case of $\mathrm{BKV}=6.3 \times 10^{5}$ copies $/ \mathrm{ml}$, a decrease in viral load in the cells was observed. The decrease in viral load does not correlate with the concentration of the antibiotic. For ciprofloxacin $125 \mu \mathrm{g} / \mathrm{ml}$, a decrease in the number of copies of the virus was noted at $0.79 \mathrm{log}$, whereas at concentrations of $62.5 \mu \mathrm{g} / \mathrm{ml}$ and $31.25 \mu \mathrm{g} / \mathrm{ml}$ it was $1 \mathrm{log}$ decrease, compared to the BKV control. At the $6.3 \times 10^{3}$ copies/ml virus dose there is no visible effect of the 
chemotherapeutic on the virus replication. For the $6.3 \times 10^{2}$ copies $/ \mathrm{ml}$ dose, negative results were obtained for all tested samples. Both infectious doses $\left(6.3 \times 10^{3} ; 6.3 \times 10^{2}\right.$ copies $\left./ \mathrm{ml}\right)$ of BKV are too small for the virus to grow properly in vitro in Vero cells.

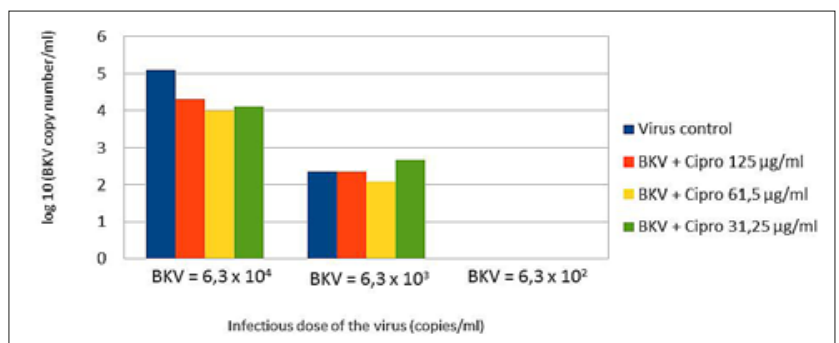

Figure 2. Effect of ciprofloxacin on BKV replication based on the infectious dose of the virus.

\section{DISCUSSION}

Polyomaviruses do not pose a threat to healthy people. The problem occurs when a person's immune system is weakened or absent [3]. Routinely used antiviral drugs, such as acyclovir, ganciclovir, ribavirin, foscarnet and cytarabine, show lack of efficacy in the treatment of polyomavirus infections [9]. Hence, there is the need to search for more effective treatment. To-date, it has been shown that antiviral activity against BKV is displayed by cidofovir CMY001, leflunomide, lactoferrin and ciprofloxacin. The results confirm that the latter of the aforementioned drugs has the best effect, both in vivo and in vitro [3, 10-16].

The necessity to look for medicines against BKV was also noted by Jeffers-Francis et al. [3]. In their research, they proved that in AIDS cases BK virus may be translocated to the salivary glands where it may cause HIV-associated salivary gland disease (HIV-SGD). For this purpose, they tested the antiviral effects of ciprofloxacin, cidofovir and leflunomide on BKV replication in salivary glands in the in vitro culture. On the basis of the experiment, the ciprofloxacin dosage nontoxic to the Vero cells was determined at $150 \mu \mathrm{g} / \mathrm{ml}$, inhibiting the virus replication, but not affecting the metabolism of cells. A similar result was obtained, in the presented study in which the highest designated ciprofloxacin concentration non-toxic to the cells was $125 \mu \mathrm{g} / \mathrm{ml}$.

In the research of Jeffers-Francis et al. [3], it was observed that the marked concentrations of drugs were non-toxic to Vero cells, but altered metabolic activity and the ability of cellular DNA replication in the cells of salivary glands. The smallest changes were observed in the case of ciprofloxacin. This demonstrates the need to monitor the activity of chemotherapeutics depending on the location of the infection.

Compared to the other two drugs, ciprofloxacin is well-tolerated and is the most effective inhibitor of viral replication in salivary glands in vitro. The drug caused the largest decrease in the BKV genome replication three days after the administration equal to 2.5-4 log, compared to the virus control where the chemotherapeutic was not added. A low selectivity index (SI) of 3.4, however, suggested a modest anti-BKV effect. Similar results were obtained in the current study, in which ciprofloxacin at $62.5 \mu \mathrm{g} / \mathrm{ml}$ and $125 \mu \mathrm{g} / \mathrm{ml}$ concentrations inhibited BKV replication by decreasing the viraemia level by $1.3-2 \log$ and $1.8-3 \log$, respectively. In addition, Jeffers-Francis et al. [3] have shown that ciprofloxacin has an inhibitory effect on the viral mRNA synthesis, both in human salivary gland cells and Vero cell lines. The inhibition of replication in both types of cells was at a similar level, therefore ciprofloxacin seems to be a better choice for people with AIDS, since in these cases the virus may be located in different organs.

In 2005, Leung et al. [15] conducted a study which compared the effects of ciprofloxacin and cephalosporins in inhibiting the replication of BKV in patients who had undergone an allogeneic stem cell transplantation. The results obtained from samples of urine of patients after transplantation who were treated with ciprofloxacin, confirmed the ability of the drug to inhibit the viral replication. Patients receiving prophylactic ciprofloxacin had a significantly lower viruria level of $3 \times 10^{5}$ copies $/ \mathrm{ml}$, compared to patients receiving cephalosporins who had a viruria level of $2.6 \times 10^{9}$ copies $/ \mathrm{ml}$. Moreover, in patients receiving ciprofloxacin the increase of viruria above 3 log was observed far less often, which was associated with a lower risk of developing haemorrhagic cystitis. In the in vitro studies of urine samples for the BKV dose of $10 \mathrm{TCID}_{50}$, however, the inhibition of the viral replication was observed only in 3 out of 7 isolates ( 2 for ciprofloxacin at a concentration of $125 \mu \mathrm{g} / \mathrm{ml}$, and 1 for a concentration of $250 \mu \mathrm{g} / \mathrm{ml}$ ), whereas for the dose of 100 $\mathrm{TCID}_{50}$ of the drug it had no effect. In addition, BKV in some patients showed resistance to fluoroquinolone. The presented study confirms the ability of ciprofloxacin to inhibit the development of the BKV viraemia in vitro, the experiment, however, did not include the effect of the antibiotic on virus derived from clinical specimens from patients. The isolates of the virus obtained for the analysis were obtained from a commercial collection of virus. There is a suggestion to expand research on the ciprofloxacin effect evaluation.

Differences in the results of research published by different researchers may be due to the genetic variation of the virus. An important part which determines the variability of the virus is the non-coding control region (NCCR) which has 2 forms. One of them is stable, called "archetype", and the other is a form altered by mutations. This region encodes information necessary for the expression of viral proteins, including the capsid protein VP1, which is responsible for binding to host cell receptors [17, 18]. Karalic et al. [19] conducted a study which was designed to characterize the molecular profile of the BK virus in patients infected with HIV. For this purpose, urine samples were taken from both healthy subjects and patients with AIDS. BK virus genome fragments characteristic of the NCCR region and the VP1 protein were analyzed by PCR. The results of the analysis showed that in HIV-infected individuals BC1 loop mutations for VP1 protein occurred. These mutations were accompanied by a decrease in CD4+ cells below 200 cells $/ \mathrm{mm}^{3}$ due to loss of immunity. It has been shown that the increase in immunosuppression affects the frequency of these mutations. This can affect the genotypic variability of the virus, and thus change the sensitivity to drugs. In the inhibition of the BKV replication, early initiated prevention is crucial. This is especially important in the development of BKV-associated nephropathy (BKVN). The most effective treatment in this case is the inhibition of immunosuppression, which can lead to graft loss. In order to avoid it, it is worth introducing treatment as soon as possible. It led Farasati et al. [12] to investigate the effect of different concentrations 
of leflunomide on the viral replication at different infectious doses. The results confirmed the effect of the infectious dose of the virus on leflunomide activity in the in vitro culture. Decreasing the BKV infectious dose resulted in an increase in the selectivity index (SI) from $0.95 \pm 1.05$ to $3.8 \pm 0.8$. This value, however, is too low to decide on the success of the treatment, which is further determined by the toxicity of the drug. Hence, the attempts in own studies by the authors of the current study to monitor the effects of ciprofloxacin at different levels of the BK viral infection. Unfortunately, they failed to observe the effect of the drug on the low infectious dose of the virus. The selected virus doses of $6.3 \times 10^{2}-$ $6.3 \times 10^{4}$ copies $/ \mathrm{ml}$ were too small for the virus to replicate properly in vitro in Vero cells.

Researchers such as Gabardi et al. [16] and Wojciechowski et al. [20] investigated the effects of ciprofloxacine on the prophylaxis of the BKV infection in immunosuppressed individuals. The results of their study confirmed that a lower viraemia level was observed in patients receiving prophylactic ciprofloxacin, compared to the placebo group, in whom the antibiotic was not administrated. In addition, from studies conducted by Wojciechowski, based on the results obtained after 3, 6, 9 and 12 months after transplantation, it was concluded that it is worth considering the introduction of prolonged prophylaxis during the most intense immunoupression, i.e. between 3-6 months after transplantation.

The clinical efficacy of ciprofloxacin in the in vivo studies has been confirmed by the in vitro studies in the presented study. Research is continuing.

\section{CONCLUSIONS}

It has been observed that ciprofloxacin exhibits antiviral activity against the $\mathrm{BK}$ virus, inhibiting its most effective replication in vitro in Vero cell line at a dose of $125 \mu \mathrm{g} / \mathrm{ml}$. Inhibition of the BKV replication is best observed after virus infection at a dose of $6.3 \times 10^{5}$ copies $/ \mathrm{ml}$.

\section{REFERENCES}

1.Świątek $€$, Polz-Dacewicz M. Polyomaviruses as etiological agents of human diseases - a review. In Polz-Dacewicz M, editor. Viral infection - diagnostics, prevention and control: the role of viral infection in public health. Lublin; 2010; p. 29-36.

2. Jozpanahi M, Ramezani A, Ossareh S, Banifazl M, Bavand A, Mamishi $\mathrm{S}$ et al. BK Viremia among Iranian Renal Transplant Candidates. Iran J Pathol. 2016; 11(3): 210-215.
3. Jeffers-Francis LK, Burger-Calderon R, Webster-Cyriaque J. Effect of Leflunomide, Cidofovir and Ciprofloxacin on replication of BKPyV in a salivary gland in vitro culture system. Antiviral Res. 2015; 118: 46-55. 4. Flores V, Rodríguez-Sánchez B, Marín-Jiménez I, Bouza E, Menchén L, Muñoz P. Prospective Study of BK Virus Infection in Patients with Inflammatory Bowel Disease. The Scientific World Journal, vol. 2014, Article ID 970528, 6 pages, 2014. doi:10.1155/2014/970528

5. Hariharan S. BK virus nephritis after renal transplantation. Kidney Int. 2006; 69(4): 655-662.

6. Acott PD, O'Regan PA, Lee SH, Crocker JF. Utilization of Vero cells for primary and chronic BK virus infection. Transplant Proc. 2006; 38(10): 3502-3505.

7. Ali SH, Chandraker A, DeCaprio JA. Inhibition of Simian virus 40 large $\mathrm{T}$ antigen helicase activity by fluoroquinolones. Antivir Ther. 2007; 12: 1-6.

8. Arthur RR, Dagostin S, Shah KV. Detection of BK virus and JC virus in urine and brain tissue by the polymerase chain reaction. Journal of Clinical Microbiology. 1989; 27(6): 1174-1179.

9. Matłosz B, Durlik M. Śródmiąższowe zapalenie nerki przeszczepionej wywołane wirusem Polyoma BK. Przegl Eidemiol. 2006; 60(1): 133-140.

10. Longhi G, Pietropaolo V, Mischitelli M, Longhi C, Conte MP, Marchetti M, Tinari A, Valenti P, Degener AM, Seganti L, Superti F. Lactoferrin inhibits early steps of human BK polyomavirus infection. Antiviral Res. 2006; 72:145-152.

11. Rinaldo $\mathrm{CH}$, Gosert R, Bernhoff E, Finstad S, Hirsch HH. 1-O-hexadecyloxypropyl cidofovir (CMX001) effectively inhibits polyomavirus BK replication in primary human renal tubular epithelial cells. Antimicrob Agents Chemother. 2010; 54: 4714-4722.

12. Farasati NA, Shapiro R, Vats A, Randhawa P. Effect of leflunomide and cidofovir on replication of BK virus in an in vitro culture system. Transplantation. 2005; 79: 116-118.

13. Bernhoff E, Tylden GD, Kjerpeseth LJ, Gutteberg TJ, Hirsch HH, Rinaldo C.H. Leflunomide inhibition of BK virus replication in renal tubular epithelial cells. J Virol. 2010; 84: 2150-2156.

14. Bernhoff E, Gutteberg TJ, Sandvik K, Hirsch HH, Rinaldo CH. Cidofovir inhibits polyomavirus BK replication in human renal tubular cells downstream of viral early gene expression. Am J Transplant. 2008; 8: 1413-1422.

15. Leung AY, Chan MT, Yuen KY, Cheng VC, Chan KH, Wong CL et al. Ciprofloxacin decreased polyoma BK virus load in patients who underwent allogeneic hematopoietic stem cell transplantation. Clin Infect Dis. 2005; 40: 528-537.

16. Gabardi S, Waikar SS, Martin S, Roberts K, Chen J, Borgi L et al. Evaluation of fluoroquinolones for the prevention of BK viremia after renal transplantation. Clin J Am Soc Nephrol. 2010; 5(7): 1298-1304.

17. Sharma PM, Gupta G, Vats A, Shapiro R, Randhawa PS. Polyomavirus BK non-coding control region rearrangements in health and disease. $J$ Med Virol. 2007; 79: 1199-1207.

18. Jin L, Gibson PE, Knowles WA, Clewley JP. BK virus antigenic variants: sequence analysis within the capsid VP1 epitope. J Med Virol. 1993; 39: $50-56$.

19. Karalic D, Lazarevic I, Banko A, Cupic M, Jevtovic D, Jovanovic T. Molecular characterization of BK virus in patients infected with human immunodeficiency virus. Med Microbiol Immunol. 2016; 205(2):185-193.

20. Wojciechowski D, Chanda R, Chandran S, Lee B, Webber A, Macaraig M et al. Ciprofloxacin prophylaxis in kidney transplant recipients reduces BK virus infection at 3 months but not at 1 year. Transplantation. 2012; 94(11): 1117-1123. 